Click www.researchjournal.co.in/online/subdetail.html to purchase.

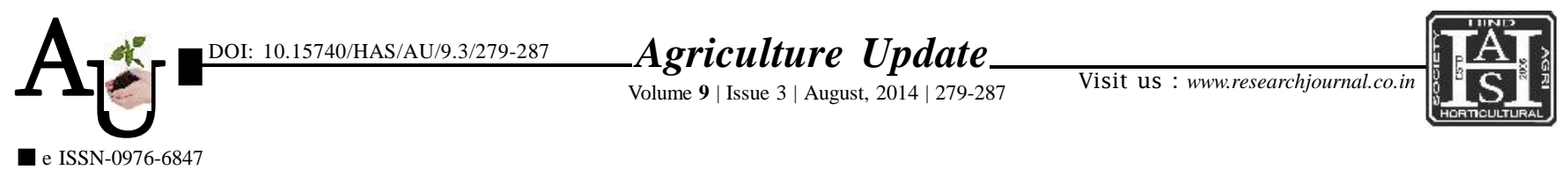

Research Article

\title{
Constraints and obstacles perceived by extension personnel in application of information and communication technology in agriculture
}

\author{
IS.R. VERMA, F.L. SHARMA, N. SINGH, K. CHAYAL AND N.R. MEENA
}

Article Chronicle : Received :

14.03.2013;

Revised :

17.05.2014;

Accepted :

03.06.2014

KEY WoRDS:

ICT application, Constraints, Obstacles, Agriculture, Extension personnel

\begin{abstract}
SUMMARY : In India about 760 millions of farmers are engaged in agriculture. According to an estimate more than 60 per cent of the farmers have no access to any source of modern agriculture information. Reaching to these unreached farmers is a great big challenge before the extension system. To achieve growth rate more than four per cent in agriculture, ICT revolution in India must be preceded by the next generation of technology and infrastructure development. Application of ICTs in agriculture should be increased. ICT must be used to reach small and marginal farmers, who are the vast majority of Indian farmers and often unable to access agriculture informations. Presently extension personnel of both government and non-government organisations are using various information and communication technologies for transfer of agriculture technologies among the farming community but they are facing many constraints and obstacles in ICT application. Therefore, the entire study was carried out in Udaipur district of Rajasthan state to identify the problems and obstacles perceived by extension personnel in use of information and communication technology. A total of 160 extension personnel ( 80 from GO and 80 from NGOs) were selected from One GO and eight NGOs. To study constraints being faced in ICT application five commonly used ICT tools namely computer, Internet, mobile phone, Kisan call centre and information kiosks were selected. Data from the respondents were collected through face to face interview technique with the help of developed instrument. The findings of the study revealed that more than two-third of the extension personnel perceived either medium or higher level of the constraints regarding ICT application in agriculture, It was also found that extension personnel of government organisation faced more constraints than NGOs personnel in the application of computer, Internet, mobile phone, Kisan call centre and information kiosk in agriculture.
\end{abstract}

How to cite this article : Verma, S.R., Sharma, F.L., Singh, N., Chayal, K. and Meena, N.R. (2014). Constraints and obstacles perceived by extension personnel in application of information and communication technology in agriculture. Agric. Update, 9(3): 279-287.

Author for correspondence :

\section{S.R. VERMA}

Krishi Vigyan Kendra,

(M.P.U.A.T.) BUNDI

(RAJASTHAN) INDIA

Email: verma.vermasr

@ gmail.com

See end of the article for

authors' affiliations 